\title{
Daily variation of zooplankton abundance and evenness in the Rosana reservoir, Brazil: biotic and abiotic inferences
}

\author{
Érica M. Takahashi, Fábio A. Lansac-Tôha, Juliana D. Dias \& Claudia C. Bonecker
} Programa de Pós-Graduação em Ecologia de Ambientes Aquáticos Continentais, Nupélia, Universidade Estadual de Maringá, Av. Colombo, 5790, 87020-900, Maringá, PR, Brazil.
(julianadeo@hotmail.com)

\begin{abstract}
The zooplankton community presents stochastic temporal fluctuation and heterogeneous spatial variation determined by the relationships among the organisms and environmental conditions. We predicted that the temporal and spatial zooplankton distribution is heterogeneous and discrete, respectively, and that the daily variation of most abundant species is related to environmental conditions, specifically the availability of resources. Zooplankton samples were collected daily at three sampling stations in a lateral arm of the Rosana Reservoir (SP/PR). The zooplankton did not present significant differences in abundance and evenness among sampling stations, but the temporal variation of these attributes was significant. Abiotic variables and algal resource availability have significantly explained the daily variation of the most abundant species $(p<0.001)$, however, the species distribution makes inferences on biotic relationships between them. Thus, not only the food resource availability is influential on the abundance of principal zooplankton species, but rather a set of factors (abiotic variables and biotic relationships).
\end{abstract}

KEYWORDS. Temporal variation, rotifers, microcrustaceans, coexistence, competition.

RESUMO. Variação diária da abundância e equitabilidade do zooplâncton no reservatório de Rosana, Brasil: inferências bióticas e abióticas. A comunidade zooplanctônica apresenta flutuação temporal estocástica e variação espacial heterogênea que são determinadas pelas relações entre os organismos e condições ambientais. Acredita-se que a distribuição temporal e espacial do zooplâncton seja heterogênea e discreta, respectivamente; e que a variação diária das espécies mais abundantes está relacionada às condições ambientais, principalmente, disponibilidade de recursos. As amostras de zooplâncton foram coletadas diariamente em três estações de amostragem em um braço lateral do reservatório de Rosana (SP/PR). O zooplâncton não apresentou diferenças significativas na abundância e equitabilidade entre as estações de amostragem, no entanto, a variação temporal desses atributos foi significativa. As variáveis abióticas e a disponibilidade de recurso algal explicou significativamente a variação diária das espécies mais abundantes $(p<0,001)$, entretanto, a distribuição das espécies faz inferências sobre relações bióticas entre elas. Assim, não só a disponibilidade de recurso alimentar é influente na abundância das principais espécies zooplanctônicas, mas sim um conjunto de fatores (variáveis abióticas e relações bióticas).

PALAVRAS-CHAVE. Variação temporal, rotíferos, microcrustáceos, coexistência, competição.

Several studies have pointed out the effects of monthly and yearly variations in environmental variables on the structure of aquatic communities. Zooplankton organisms commonly present variations in abundance over several time scales (Marazzo \& Valentin, 2000), including short time scales (LIENESCH \& MATTHEWs, 2000). Tropical zooplankton dynamics has been reported with seasonal and yearly fluctuations, although there is some discussion about the importance of events occurring over short time periods, such as monthly or daily as they relate to the dynamics of aquatic communities (FonseCA, 1997; Borges et al., 2008; Hernández-Trujillo et al., 2010).

Spatially, zooplankton may occur in patches, even in relatively homogeneous environments, such as the limnetic region of a lake (LAMPERT \& SOMMER, 1997). However, this heterogeneous distribution (patches) has profound effects for the understanding and modeling of population dynamics and its interactions with other organisms, including interactions in different compartments of the environment, and consequently, present important implications for the structure and functioning of ecosystems. The factors responsible for the zooplankton patchiness arise from a great variety of physical and biotic processes, such as predation and competition (PINEL-Alloul \& Pont,
1991; Pinel-Alloul et al., 1995), and a heterogeneous distribution may be a result of the interaction between these processes, in addition to the influence of abiotic factors (multiple forces hypothesis; PInel-Alloul, 1995). The paradox of plankton (HuTCHinson, 1961) describes a contradiction between the competitive exclusion principle and phytoplankton species diversity, seeking to explain how so many species coexist in a relatively homogeneous environment.

Among zooplankton groups it is known the exploitative competition and/or interference competition (indirect competition) between large cladocerans and rotifers (Gilbert, 1988; DeMotT, 1989). In the exploitative competition, the shortage of resources used by these groups may lead to reduced reproductive rates, physiological stress or even the death of organisms by starvation. Nevertheless, in the interference competition, rotifers may occasionally enter the filtering chamber of cladocerans during the process of food capture.

This study was accomplished using daily samplings of a zooplankton community in a lateral arm of the Rosana Reservoir (São Paulo/Paraná), testing the hypothesis that the temporal and spatial zooplankton distributions are heterogeneous and discrete, respectively. We also predicted 
that the daily variation of populations of the most abundant species is related to availability of food resources.

\section{MATERIALS AND METHODS}

Study area. This study was accomplished in one lateral arm (Corvo River, 22 $2^{\circ} 39^{\prime} \mathrm{S} ; 52^{\circ} 46^{\prime} \mathrm{W}$ ), located in the lacustrine region of the Rosana Reservoir (Paranapanema River, Paraná River basin) (Fig. 1). This reservoir presents

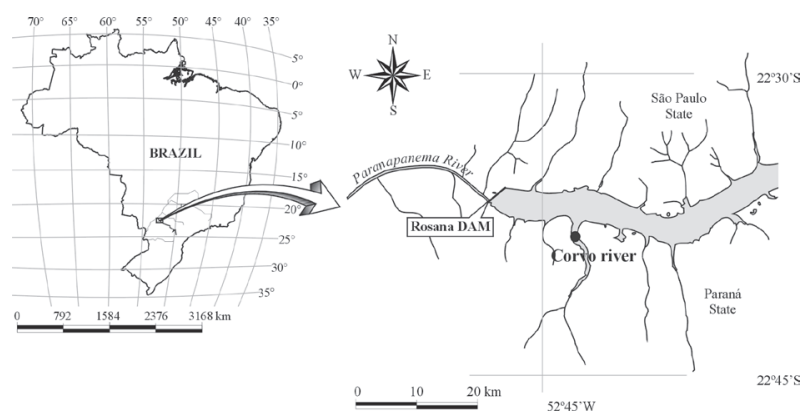

Fig. 1. Study area at the Corvo River in the Rosana Reservoir, São Paulo/ Paraná, Brazil.

$220 \mathrm{~km}^{2}$ of area, $116 \mathrm{~km}$ of extension, mean depth of $12 \mathrm{~m}$ in fluvial and transition regions, and $30 \mathrm{~m}$ in the lacustrine region. The mean residence time is 18.6 days (CESP, 1998). The precipitation was low during this study, with a mean of $3.84 \mathrm{~L} \mathrm{~m}^{-3}$ (Borges et al., 2008).

Sampling and analyses. Zooplankton samplings were carried out daily over 15 days during the summer (from November $23^{\text {th }}$ to December $7^{\text {th }}, 2003$ ) at three sampling stations (S1, S2 and S3) about $500 \mathrm{~m}$ from each other in the limnetic region of Corvo River. After this period, samplings were performed every three days until 16 December $(n=54)$. Samples were obtained under the water's surface, always in the morning, using a motorized pump and $68 \mu \mathrm{m}$ plankton net to filter 200 liters of water per sample, and preserved in $4 \%$ formaldehyde buffered with calcium carbonate.

Concomitant with zooplankton samplings, some physical and chemical water variables were measured: dissolved oxygen $\left(\mathrm{mg} \mathrm{L}^{-1}\right)$, water temperature $\left({ }^{\circ} \mathrm{C}\right.$; oximeter coupled with thermometer), electrical conductivity $(\mu \mathrm{S} \mathrm{cm}-$ ', Digimed field potentiometer), $\mathrm{pH}$ (digital potentiometer) and turbidity (NTU; digital portable turbidimeter). The concentrations of the total phosphorus $\left(\mu \mathrm{g} \mathrm{L}^{-1}\right)$ and nitrogen ( $\left.\mu \mathrm{g} \mathrm{L}^{-1}\right)$ were determined according to MACKERETH et al. (1978). The phytoplankton samples were collected with glass bottles and preserved in 1\% Lugol's solution. Phytoplankton biomass $\left(\mathrm{mm}^{3} \mathrm{~L}^{-1}\right)$ was obtained by multiplying population density by volume of individuals (WeTZel \& LiKens, 2000).

The zooplankton species were identified according to a specialized bibliography. The abundance (ind $\mathrm{L}^{-1}$ ) was estimated from three subsequent subsamples from each sample, which were obtained via a Hensen-Stempel pipette. At least $10 \%$ of the concentrated sample was counted in a Sedgewick-Rafter chamber under an optical microscope
(BotTrell et al., 1976). Samples with few individuals (less than 50) were integrally counted.

The evenness index (PIELOu, 1966) was evaluated for each day and sampling station. This result was obtained using the expression $\mathrm{H}^{\prime} / \mathrm{H}_{\max }$, where $\mathrm{H}^{\prime}$ is the ShannonWiener diversity index and $\mathrm{H}_{\max }$ is the diversity under the maximum condition of uniformity.

In order to evaluate the temporal (sampling days) and spatial (sampling stations) variations of evenness and the abundance of the total zooplankton, rotifers, cladocerans, cyclopoid and calanoid copepods, a KruskalWallis ANOVA was employed.

Moreover, a redundancy analysis (RDA; LEGENDRE \& LEGENDRE, 1998) was used to reduce the data dimensionality and identify the relationships between the abundance of major zooplankton species (those contributing with at least $3 \%$ of the abundance of each group) and the abiotic variables and algae resource availability (phytoplankton biomass). The significance $(p<0.05)$ was evaluated through randomizations. For this analysis, we transformed the abundance of principal zooplankton species using the Hellinger method (LEGENDRE \& GALLAGHER, 2001) prior to analyses. Autocorrelated environmental variables were checked by calculating the variance inflation factor (VIF) and were removed of this analysis.

All statistical analyses were run with the R-cran 2.14.1 software (R Development Core Team, 2011) using the Biodiversity R package (KINDT \& COE, 2005) and the vegan package (OKSANEN et al., 2011).

\section{RESULTS}

Abiotic variables and the algae resource availability. Dissolved oxygen concentration was higher at the $2^{\text {nd }}$ sampling day $\left(7.6 \mathrm{mg} \mathrm{L}^{-1}\right)$ and lower, at the $18^{\text {th }}$ day $\left(5.9 \mathrm{mg} \mathrm{L}^{-1}\right)$. Water temperature ranged from $26.1\left(18^{\text {th }}\right.$ day) to $29.6^{\circ} \mathrm{C}\left(24^{\text {th }}\right.$ day $)$. The highest value of conductivity was registered at the $3^{\text {rd }}$ day $\left(52.3 \mu \mathrm{S} \mathrm{cm}^{-1}\right)$ and the lowest at the $11^{\text {th }}$ day $\left(34.8 \mu \mathrm{S} \mathrm{cm}^{-1}\right)$. The $\mathrm{pH}$ varied between 6.3 $\left(11^{\text {st }}\right.$ day $)$ and $7.0\left(2^{\text {nd }}, 3^{\text {rd }}, 4^{\text {th }}\right.$ and $7^{\text {th }}$ days $)$. Turbidity ranged from 2.2 ( $3^{\text {rd }}$ day) and 29.8 NTU ( $18^{\text {th }}$ day). The greatest concentration of total nitrogen was recorded at the $6^{\text {th }}$ sampling day $\left(413.8 \mu \mathrm{g} \mathrm{L}^{-1}\right)$, and of total phosphorus, at the $18^{\text {th }}$ day $\left(26.3 \mu \mathrm{g} \mathrm{L}^{-1}\right)$. The average values of phytoplankton biomass ranged from $0.4 \mathrm{~mm}^{3} \mathrm{~L}^{-1}$, on day 9 , to $7.1 \mathrm{~mm}^{3}$ $\mathrm{L}^{-1}$ on day 6 of study (Tab. I), and Cyanobacteria was the group responsible for the highest biomass.

Zooplankton abundance and evenness. The abundance and evenness of the total zooplankton, rotifers, cladocerans, calanoid and cyclopoid copepods did not present expressive variations among the sampling stations, and consequently, their spatial variation was not significant to the 0.05 level. On the other hand, the abundance of total zooplankton and all groups were significantly distinct over time (daily variation), and considering the evenness values, the total zooplankton, rotifers and cladocerans presented significant temporal variation (Figs 2-11; Tab. II). Thus, 
Tab. I. Mean values/standard deviation of abiotic variables and phytoplankton biomass recorded in the Corvo River during the study period. Data missing for days 8, 10, 12 and 14 (DO, dissolved oxygen; Temp, water temperature; Cond, electric conductivity; Turb, turbidity; TN, total nitrogen; TP, total phosphorus; Phy, phytoplankton biomass).

\begin{tabular}{|c|c|c|c|c|c|c|c|c|}
\hline Days & $\begin{array}{c}\mathrm{DO} \\
\left(\mathrm{mg} \mathrm{L}^{-1}\right)\end{array}$ & $\begin{array}{l}\text { Temp } \\
\left({ }^{\circ} \mathrm{C}\right)\end{array}$ & $\begin{array}{c}\text { Cond } \\
\left(\mu \mathrm{S} \mathrm{cm}^{-1}\right)\end{array}$ & $\mathrm{pH}$ & $\begin{array}{c}\text { Turb } \\
\text { (NTU) }\end{array}$ & $\begin{array}{c}\mathrm{TN} \\
\left(\mu \mathrm{g} \mathrm{L}^{-1}\right)\end{array}$ & $\begin{array}{c}\mathrm{TP} \\
\left(\mu \mathrm{g} \mathrm{L}^{-1}\right)\end{array}$ & $\begin{array}{c}\text { Phy } \\
\left(\mathrm{mm}^{3} \mathrm{~L}^{-1}\right)\end{array}$ \\
\hline 1 & $6.9 / 0.2$ & $26.5 / 0.1$ & $35.0 / 1.2$ & $6.9 / 0.1$ & $4.0 / 0.1$ & $340.5 / 25.1$ & $9.7 / 0.8$ & $1.7 / 2.4$ \\
\hline 2 & $7.6 / 0.1$ & $28.2 / 0.0$ & $40.0 / 1.2$ & $7.0 / 0.0$ & $2.8 / 0.1$ & $409.0 / 19.9$ & $9.6 / 0.4$ & $0.6 / 0.4$ \\
\hline 3 & $6.6 / 0.0$ & $28.8 / 0.0$ & $52.3 / 0.4$ & $7.0 / 0.0$ & $2.2 / 0.1$ & $399.4 / 5.3$ & $25.6 / 2.2$ & $3.9 / 0.8$ \\
\hline 4 & $6.4 / 0.0$ & $27.5 / 0.1$ & $44.8 / 0.4$ & $7.0 / 0.0$ & $2.5 / 0.0$ & $392.6 / 20.4$ & $13.1 / 3.4$ & $3.4 / 1.0$ \\
\hline 5 & $6.6 / 0.0$ & $26.8 / 0.1$ & $43.9 / 0.4$ & $6.7 / 0.0$ & $3.0 / 0.1$ & $346.8 / 56.7$ & $11.1 / 0.4$ & $2.4 / 1.2$ \\
\hline 6 & $6.5 / 0.1$ & $26.2 / 0.1$ & $43.3 / 0.9$ & $6.9 / 0.1$ & $6.7 / 0.9$ & $413.8 / 42.3$ & $16.8 / 2.9$ & $7.1 / 9.3$ \\
\hline 7 & $6.9 / 0.2$ & $27.3 / 0.0$ & $42.6 / 0.4$ & $7.0 / 0.0$ & $3.5 / 0.3$ & $324.9 / 69.1$ & $11.1 / 0.7$ & $1.8 / 1.0$ \\
\hline 9 & $6.6 / 0.1$ & $26.5 / 0.1$ & $37.6 / 0.3$ & $6.5 / 0.1$ & $6.6 / 0.5$ & 299.8/8.6 & $17.8 / 1.6$ & $0.4 / 0.4$ \\
\hline 11 & $6.0 / 0.3$ & $27.0 / 0.2$ & $34.8 / 5.7$ & $6.3 / 0.0$ & $11.9 / 2.6$ & $236.5 / 5.2$ & $22.4 / 0.4$ & $0.5 / 0.2$ \\
\hline 13 & $6.8 / 0.1$ & $27.9 / 0.0$ & $39.2 / 0.4$ & $6.7 / 0.0$ & $5.3 / 0.1$ & $330.0 / 18.9$ & $17.3 / 3.1$ & $4.0 / 2.0$ \\
\hline 15 & $6.4 / 0.1$ & $26.9 / 0.0$ & $36.8 / 0.6$ & $6.4 / 0.0$ & $7.6 / 0.0$ & $300.6 / 28.3$ & $21.6 / 1.5$ & $1.4 / 0.7$ \\
\hline 18 & $5.9 / 0.1$ & $26.1 / 0.1$ & $44.7 / 0.7$ & $6.7 / 0.0$ & $29.8 / 1.3$ & $339.5 / 24.1$ & $26.3 / 1.7$ & $0.6 / 0.3$ \\
\hline 21 & $6.1 / 0.1$ & $27.1 / 0.0$ & $39.1 / 0.2$ & $6.7 / 0.1$ & $16.5 / 0.1$ & $315.8 / 6.2$ & $22.0 / 1.3$ & $1.5 / 0.3$ \\
\hline 24 & $6.0 / 0.4$ & $29.6 / 0.1$ & $51.3 / 0.6$ & $6.8 / 0.0$ & $9.0 / 0.3$ & $352.6 / 18.6$ & $17.6 / 1.7$ & $4.3 / 2.9$ \\
\hline
\end{tabular}

the temporal scale of the results will be emphasized in this study.

The zooplankton abundance in each sample ranged from 37 to up 702 ind $\mathrm{L}^{-1}$. In the second week, higher abundance values were verified, including the abundance peak (Fig. 2). The rotifer abundance varied between 1 and 58 ind $\mathrm{L}^{-1}$. There were also peaks of abundance during the second week and a sharp decrease at the end of the period (Fig. 3). Cladocerans were numerically dominant, determining the fluctuation of the total zooplankton abundance. The abundance ranged from 8 to up 486 ind $\mathrm{L}^{-1}$ and the temporal variation was significant and very similar to that registered for the entire community (Fig. 4). The abundance of cyclopoid copepods ranged from 2 to up 39 ind $\mathrm{L}^{-1}$. Higher values were observed from the second week, with peaks of abundance during the second and third weeks of the study (Fig. 5). Considering the calanoids, the abundance varied between 3 and 142 ind $\mathrm{L}^{-1}$; and peaks of abundance occurred in the first and second weeks (Fig. 6).

The evenness of zooplankton showed an upward trend through the end of the second week of the study. Afterwards, the values decreased and increased again, reaching values similar to those registered in the beginning (Fig. 7). There was a slight fluctuation in the evenness of rotifer species, but clear decreases were observed at $10^{\text {th }}$, $12^{\text {nd }}$ and $21^{\text {st }}$ days (Fig. 8). Cladocerans presented the lowest evenness during the third week of the study (Fig. 9). The highest values of evenness of cyclopoids were observed in the second week (Fig. 10). The calanoids, in general, presented a lower dominance than the cyclopoids (Fig. 11).

Fluctuation of the abundance of the principal zooplankton species. The most abundant species were Conochilus coenobasis (Skorokov, 1914) (25.7\%), Synchaeta pectinata Ehrenberg, 1832 (17.4\%), Conochilus dossuarius (Hudson, 1875) (16.1\%), Conochilus unicornis Rousselet, 1892 (8.5\%), Keratella cochlearis Gosse, 1851 (8.5\%), Ascomorpha saltans (Bartsch, 1870) (6.8\%) and Gastropus hyptopus (Ehrenberg, 1938) (6.1\%). For the microcrustaceans, Ceriodaphnia cornuta Sars, 1886 (71.3\%), Daphnia gessneri Herbst, 1967 (16.0\%), Bosminopsis deitersi Richard, 1895 (4.4\%) and Bosmina hagmanni Stingelin, 1904 (3.4\%) were the most abundant cladoceran species, whereas Notodiaptomus henseni (Dahl, 1894) (69.7\%), Thermocyclops decipiens Kiefer, 1929 (19.3\%) and Thermocyclops minutus (Lowndes, 1934) $(7.0 \%)$ were the most abundant species among the copepods.

All these above mentioned rotifer species presented striking fluctuations in their abundances. Conochilus dossuarius, $C$. unicornis and $K$. cochlearis had several peaks of abundance for almost the entire period of the study, C. coenobasis during the second week, G. hyptopus only at the end of the study and A. saltans and S. pectinata in the first week. This last species also presented peaks of abundance at the end of the second week and at the beginning of the third week (Figs 12-18).

As noted for rotifers, the abundance variation of the principal cladoceran species was very clear between the sampling days. Ceriodaphnia cornuta and D. gessneri presented peaks of abundance in the second week and at

Tab. II. Results from Kruskal-Wallis ANOVA between the abundance and evenness of the total zooplankton, rotifers, cladocerans, cyclopoid and calanoid copepods) over the time (sampling days) in the Corvo River, Brazil (df, degrees of freedom; n, number of observations; H, KruskalWallis value; ns, not significant at $\mathrm{p}<0.05$ ).

\begin{tabular}{lcccc}
\hline \multicolumn{5}{c}{ Abundance } \\
\hline Zooplankton & df & $\mathrm{n}$ & $\mathrm{H}$ & $p$-value \\
\hline Rotifers & 17 & 53 & 40.48 & 0.001 \\
Cladocerans & 17 & 53 & 39.65 & 0.001 \\
Calanoids & 17 & 53 & 41.47 & 0.001 \\
Cyclopoids & 17 & 53 & 42.13 & 0.001 \\
\hline & 17 & 53 & 38.24 & 0.002 \\
\hline Zooplankton & 17 & 53 & 38.48 & 0.002 \\
Rotifers & 17 & 53 & 27.64 & 0.049 \\
Cladocerans & 17 & 53 & 41.74 & 0.001 \\
Calanoids & 17 & 53 & 18.43 & $0.362^{\text {ns }}$ \\
Cyclopoids & 17 & 53 & 22.32 & $0.172^{\text {ns }}$ \\
\hline
\end{tabular}



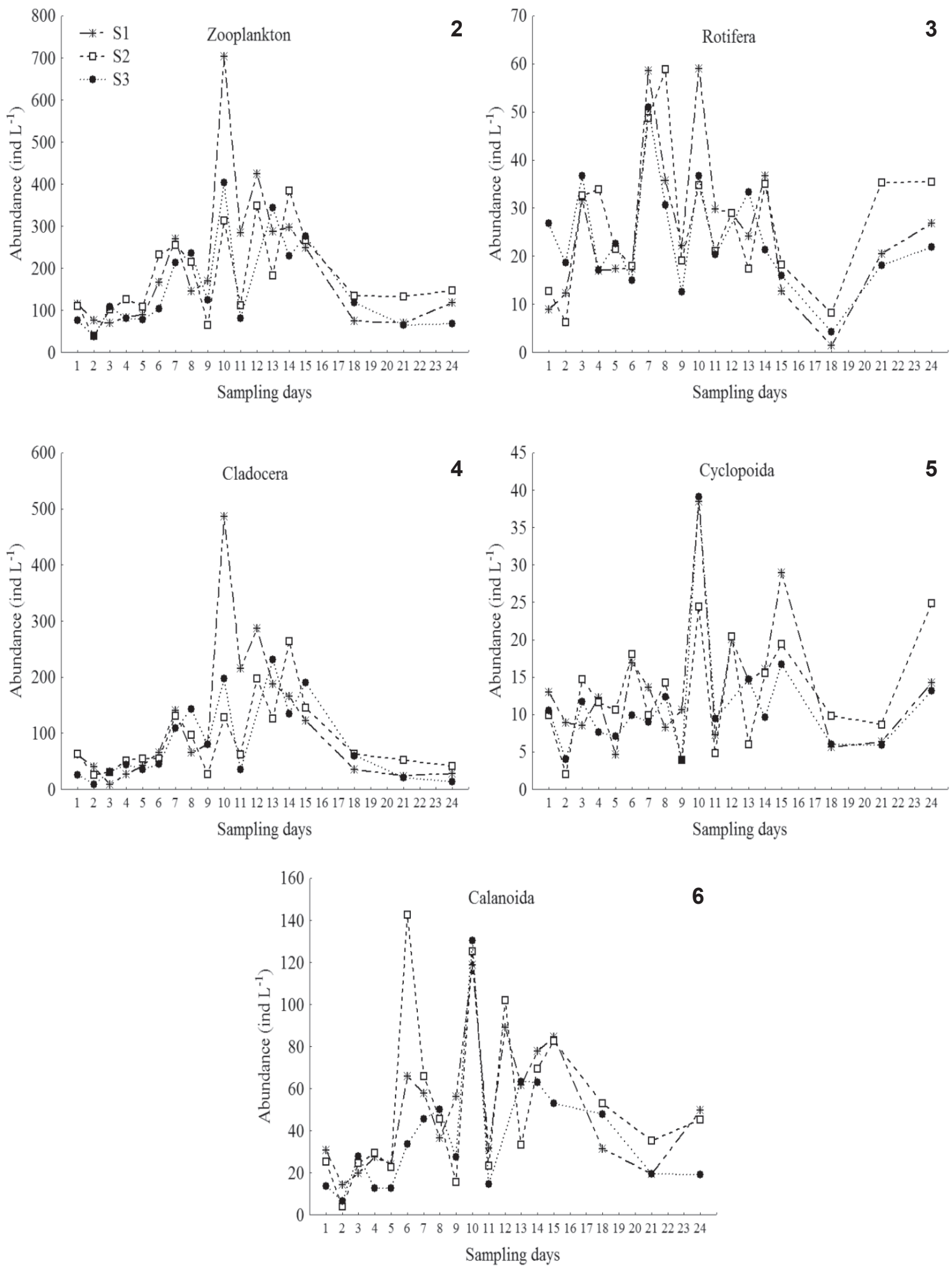

Figs 2-6. Abundance variation of the total zooplankton, rotifers, cladocerans, cyclopoid and calanoid copepods at sampling stations (S1, S2, S3) in the limnetic region of the Corvo River (São Paulo/Paraná, Brazil). 

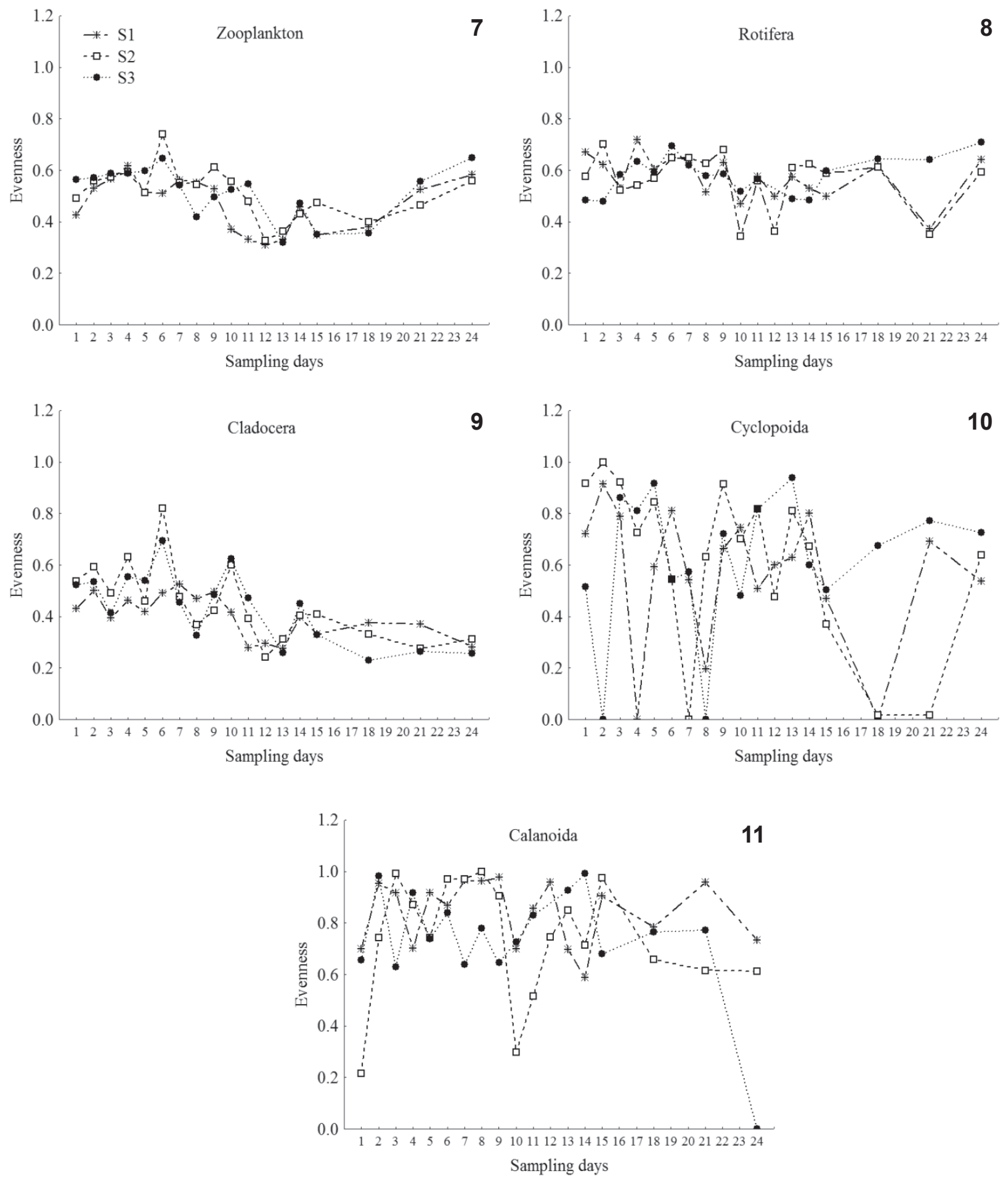

Figs 7-11. Evenness variation of the total zooplankton, rotifers, cladocerans, cyclopoid and calanoid copepods at sampling stations (S1, S2, S3) in the limnetic region of the Corvo River (São Paulo/Paraná, Brazil). 
the beginning of the third week and low abundances in the last days. Bosminopsis deitersi and B. hagmanni presented peaks of abundance at the end of the first week and during the middle of the second week, and this last species still presented one abundance peak at the end of the second week of the study (Figs 19-22).

For the most abundant copepods, the daily variation of abundance was also very clear. In general, the three species had a low abundance at the beginning of the study. Notodiaptomus henseni and T. decipiens presented relatively similar abundance fluctuations, with higher values at the end of the first and during the third weeks. Thermocyclops minutus presented peaks of abundance during the second week of the study (Figs 23-25).

Relationships between the most abundant species and the abiotic variables and the algal resource availability. The most abundant zooplankton species were significantly related to abiotic variables and availability of algal resource $(p<0.001)$. The matrix of environmental data explained $18 \%$ (adjusted $\mathrm{R}^{2}$ ) of the variation of the most abundant zooplankton species. The gradient of species characterized by the axis 1 distributed most species on the positive side, especially $S$. oblonga, B. deitersi, A. saltans and $B$. hagmanni, which were significantly influenced by higher values of dissolved oxygen. The species most representative on the negative side of the axis 1 were $G$. hyptopus and T. minutus and were positively associated with higher values of temperature and turbidity. On the axis 2 of RDA, the most representative species of the positive side (G. hyptopus, A. saltans, S. oblonga) have been related to higher values of total nitrogen, $\mathrm{pH}$ and phytoplankton biovolume. Additionally, the abundance of T. minutus was related to higher values of total phosphorus (Fig. 26).

\section{DISCUSSION}

Studies assessing the daily scale in the variation of the zooplankton community structure are important once they show patterns not observable in longer time scales, mainly in relation to the abundance fluctuation of these organisms. The community showed an increase in the number of individuals from the beginning of the study, with peaks of abundance in the middle of the study period and low values at the end of the period. Among the factors that influence this variation, we may consider changes in abiotic variables and food resource availability and biotic relationships, as competition, coexistence and predation (Hernández-Trujillo et al., 2010). Clear daily variations of the zooplankton abundance were also observed by FonseCA (1997) in a Brazilian reservoir (state of São Paulo), which were ascribed to the daily changes in the limnological variables, such as nutrient concentrations and water transparency. The abundance of the zooplankton community registered in the present study presented a pattern similar to that of phytoplankton community (BORGES et al., 2008).

The spatial variation was not significant possibly due to quite similar physical conditions of the sampling sites and low current velocity in this study area. This physical variable has been stressed as important for the heterogeneous distribution of zooplankton along the longitudinal axis of reservoirs, considering that under reduced current flow, the reproductive rate of these organisms can rise since their displacement rate is lower (MARzolf, 1990).

The variation pattern in the total zooplankton abundance was mainly influenced by the variation of cladoceran abundance because these microcrustaceans presented on average more than $50 \%$ of the individuals in the examined period. This can be assigned to the shorter time of water renewal in reservoirs, which favors the development of species with longer life cycle as microcrustaceans. The numerical predominance of microcrustaceans was also verified in 31 reservoirs from the state of Paraná (Brazil) by LANSAC-TôHA et al. (2005).

The temporal variation of evenness was significant, evidencing the predominance of some species in different times, along the sampling days, as rotifer and cladoceran species from the middle until the end of the study, with the lowest evenness registered, in general, in this phase. The variation in the evenness could be related to the food availability and to the biotic relationships among the species, such as competition, which may favor a species that will dominate the community. A high species dominance can indicate environmental stress associated with, e.g., biotic relationships, such as competition or predation (GreEN, 1993).

The abundance peaks of rotifers between days 7 and 10 were related to the high numerical contribution of $C$. coenobasis, $C$. dossuarius and A. saltans. This latter species and $C$. unicornis contributed to the increase in the abundance of the group in the last two sampling days. Synchaeta pectinata was responsible for the rotifer abundance in the beginning of the study. In the Monte Alegre Lake (state of São Paulo, Brazil), C. dossuarius was one of the main rotifer species contributing to the abundance peaks of this group (ARCIFA et al., 1992). BONECKER et al. (2002) also registered $C$. coenobasis as the most abundant rotifer species in a floodplain lake. In this way, the Conochilus populations could become abundant due to the intense individual reproduction to form new colonies and to the mucilage that avoid predation (Williamson, 1983). Synchaeta pectinata was recorded as one of the most common species in the Valle de Bravo reservoir (RAMírez-GARCIA et al., 2002). The species of Synchaeta are herbivorous and can feed on algae from just a few $\mu \mathrm{m}$ to over $50 \mu \mathrm{m}$, and they are able to consume even smaller particles (JoHANSSON, 1983). The Ascomorpha genus has the ability to suck the plasmatic content from larger phytoplanktonic algae, for example, the Cyanobacteria colonies observed in this study, which represents an adaptive strategy for these organisms (SLÁDEČEK, 1983).

In relation to the cladocerans, the increase in $C$. cornuta abundance observed at the beginning of the first week, the peaks observed in days 10 and 12 , and the posterior 

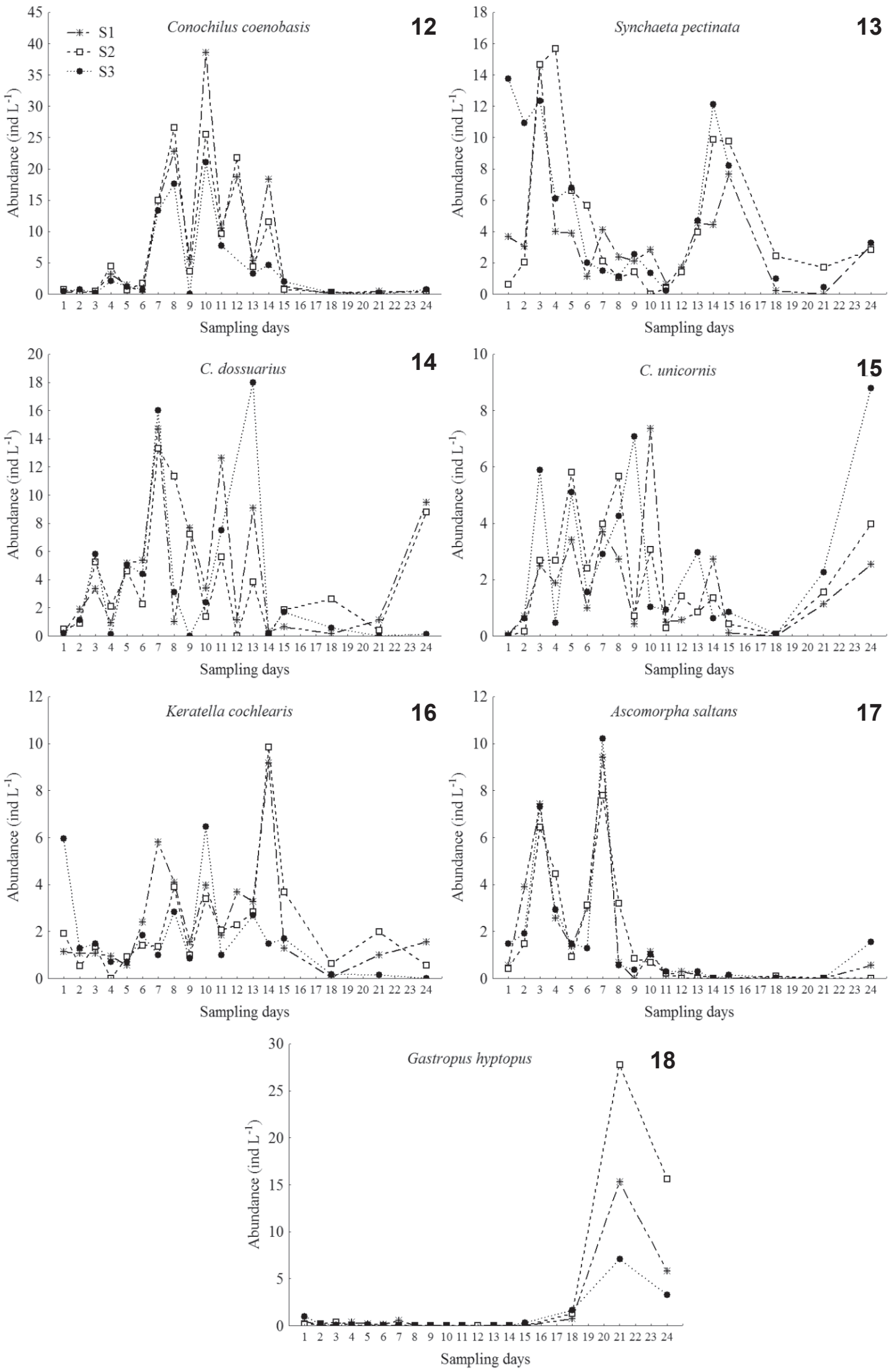

Figs 12-18. Abundance daily variation of the principal rotifer species at sampling stations (S1, S2, S3) in the limnetic region of the Corvo River (São Paulo/Paraná, Brazil) 

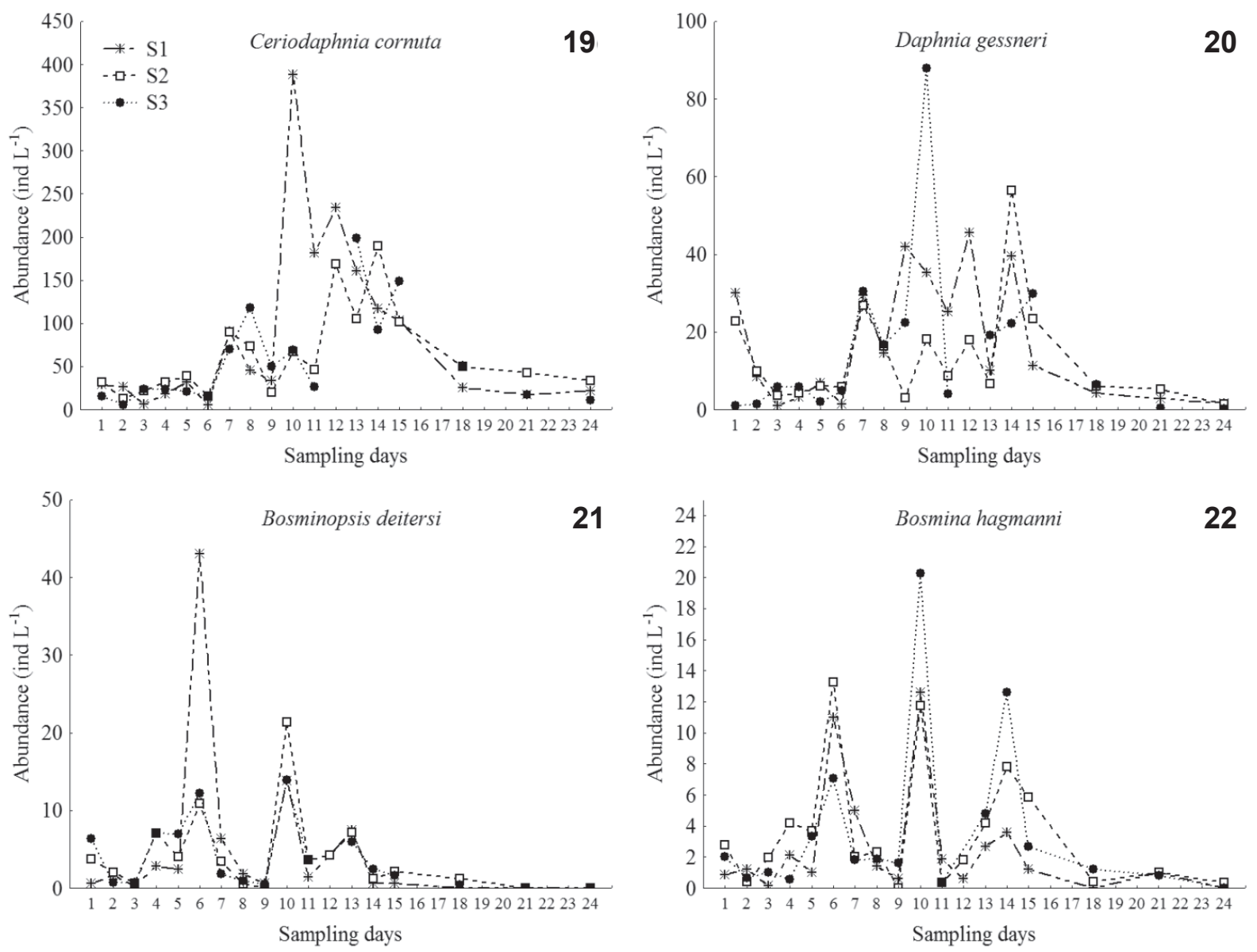

Figs 19-22. Abundance daily variation of the principal cladoceran species at sampling stations (S1, S2, S3) in the limnetic region of the Corvo River (São Paulo/Paraná, Brazil).

decrease in the number of individuals were reflected in the daily variation of the abundance of this group. Daphnia gessneri, B. deitersi and B. hagmanni also contributed to the peak of abundance verified at day 10 , besides the high values observed until day 15 . The most abundant species of cladocerans present characteristics that favor their development in the environment studied. VILLALOBOS \& GonZÁLEZ (2006) stated that, among cladoceran species, C. cornuta presents a short embryonic development, fast growing rate of young stages and quickly reaches sexual maturity, and capability to generate defense mechanisms against predation, e.g., polymorphism. The species of Daphnia are filter-feeders, capable of maintaining high filtering and ingestion rates, generate defense mechanisms (Dodson, 1974) and are capable to use efficiently all components of the microbial loop (ModenutTi et al., 2003). Considering Bosmina, DeMott \& Kerfoot (1982) argue that the species from this genus may combine the passive filtering with the active capture of particles, and they are capable of distinguishing food particles. This fact can provide an advantage in food capture, favoring the development of their populations. Bosminopsis deitersi presents continuous reproduction over time, with high turnover rates when compared with other cladocerans species, reflecting the high reproductive rates and short time of its development (MELÃo \& RoCHA, 2006).

The higher abundance of the calanoid Notodiaptomus henseni can be related to the relatively wide food spectrum that favors its development. MATSUMURA-TUNDISI \& TUNDISI (2005) said that one Notodiaptomus species can feed on bacteria, small food particles and also on algae $<20$ $\mu \mathrm{m}$. Thermocyclops decipiens and T. minutus have been highlighted by their relationship of coexistence in Brazilian reservoirs (Sendacz, 1984; Lopes et al., 1997; Nogueira, 2001).

Biotic and abiotic environmental variables were associated with the abundance variation of the main zooplankton populations, despite the low explanation (18\%) of the RDA analysis. In ecological studies the low explanation of analysis is expected given the complexity of factors operating on the community structure (TER BRAAK \& Prentice, 1988).

Synchaeta oblonga, B. deitersi, A. saltans and B. hagmanni were related to higher values of dissolved oxygen. This result may indicate an indirect relationship of these species with phytoplankton biomass, because higher values of dissolved oxygen indicate higher primary production. In agreement with HofFMANN (1977), the concentration 

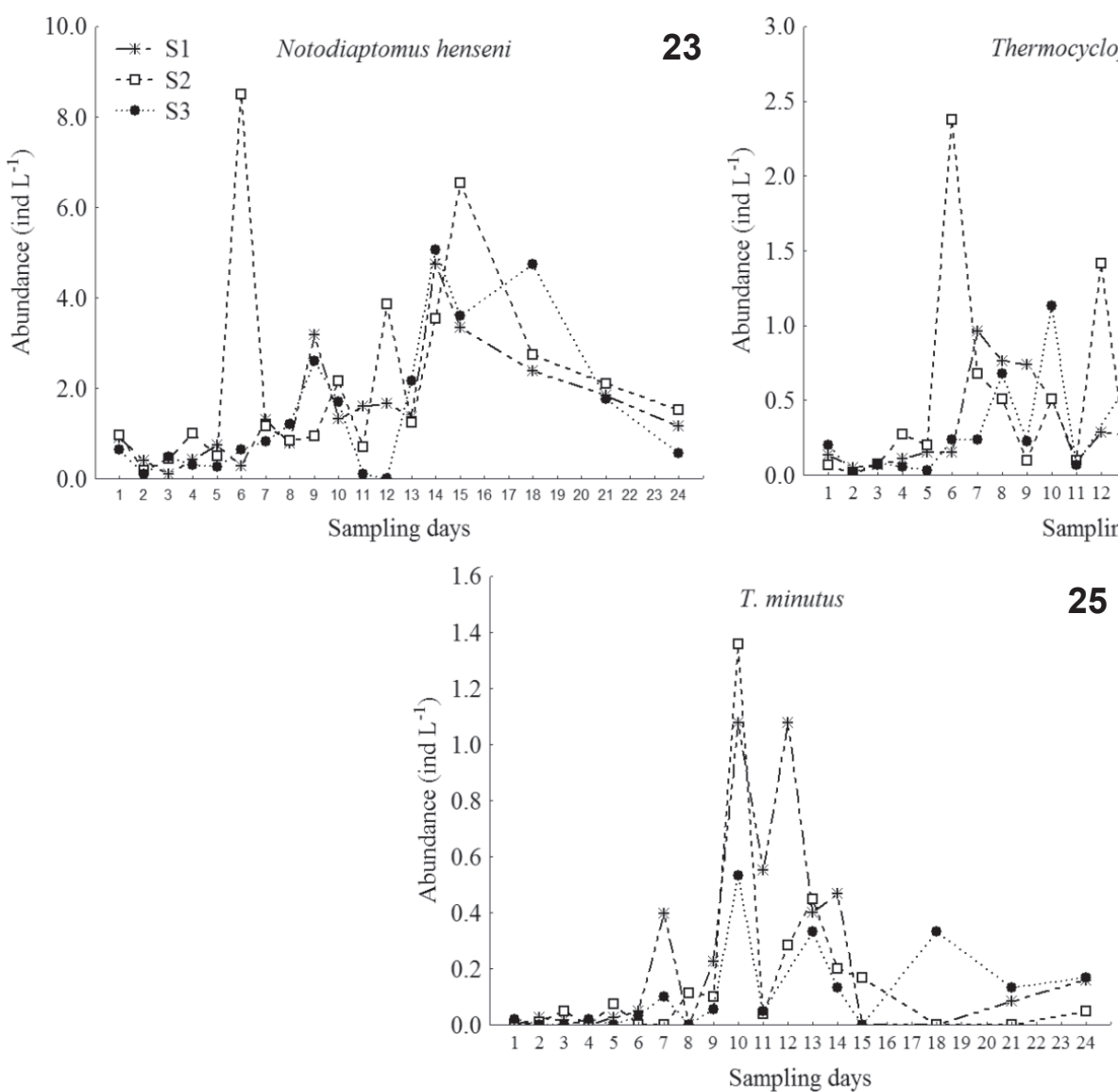

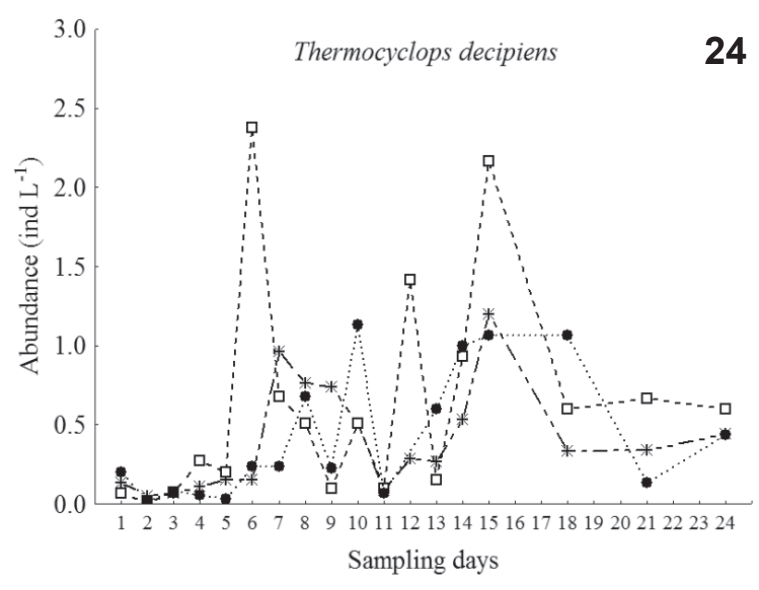

25

Figs 23-25. Abundance daily variation of the principal copepods species at sampling stations (S1, S2, S3) in the limnetic region of the Corvo River (São Paulo/Paraná, Brazil).

of dissolved oxygen in the water plays a significant role in determining the occurrence and abundance of zooplankton species.

Temperature and turbidity were related with the abundance of G. hyptopus e T. minutus. Temperature is a variable highly associated with the abundance of zooplankton organisms because it works directly on intrinsic features of organisms, such as birth rate, growth, mortality and fecundity (LeHman, 1988; Melão, 1999). The increase in turbidity may favor larger species like the copepod T. minutus, once it hinders the visualization of the prey by the predator. Furthermore, depending on the quality of suspended matter, this can serve as food for zooplankton organism, contributing to higher abundance values.

We verified associations between the abundance of G. hyptopus, A. saltans and S. oblonga and the total nitrogen, $\mathrm{pH}$ and phytoplankton biomass that represents the food resource availability. Some rotifer species can be benefited under increased availability of resources, because they rapidly consume these resources and invest in reproduction, increasing thus their populations. The phytoplankton as food resource for the rotifers population development was demonstrated by BONECKER \& LANSACTôHa (1996) and Aoyagui et al. (2003). The relationship between T. minutus and total phosphorus can also indicate an indirect relationship with phytoplankton.
Most species grouped, which in turn points that they support similar environmental conditions and present biotic interactions. In general, the occurrence of congeneric associations implies the existence of strategies to decrease competitive relationships; e.g., spatial segregation or differences in the filtering apparatus may reduce the exploitative competition (SANDERCOCK, 1967).

The coexistence of closely related organisms is possible through spatial and temporal segregation. The differentiated distribution of several species suggests an adaptive strategy that favors the coexistence of numerous species in the same environment (MATSUMURA-TUNDISI et al., 1990). Thus, this coexistence may include species from the same group or consider species from distinct zooplankton groups. For example, the existence of rotifer species may be related to their food variability, which allows resource partitioning (POURRIOT, 1977).

According to DeMoтt (1989), strong effects of interspecific competition are well documented among zooplankton species. There is strong evidence of the competitive superiority of cladocerans with respect to the rotifers (Gilbert, 1988; DeMott, 1989). Daphnia may negatively affect the rotifer populations through exploitative and/or interference competition (SARNELLE, 1997). ArCIFA et al. (1992), who studied zooplankton in a tropical reservoir, observed the competitive superiority of 


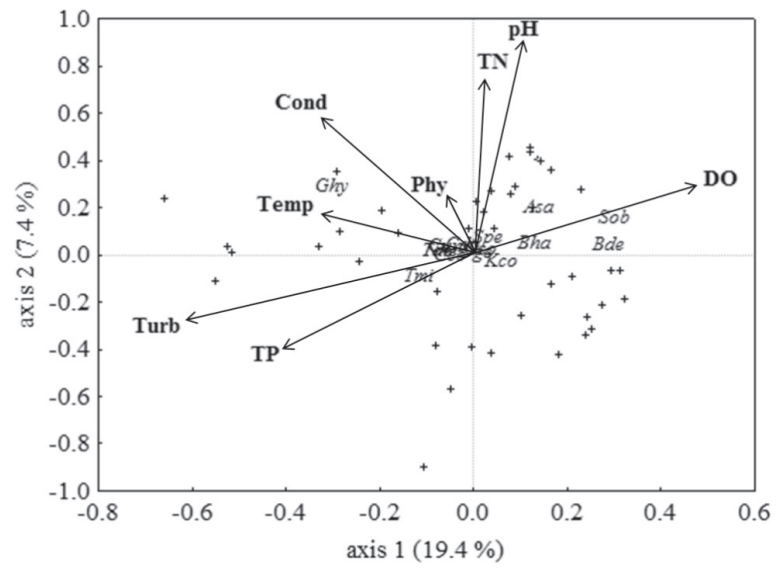

Fig. 26. Relationship of the most abundant species with abiotic variables and availability of algal resources, according to the redundancy analysis (Temp, temperature; DO, dissolved oxygen; Cond, electrical conductivity; Turb, turbidity; TN, total nitrogen total; TP, total phosphorus; Phy, phytoplankton biomass; Cco, C. coenobasis; Spe, S. pectinata; Cdo, C. dossuaris; Cun, C. unicornis; Kco, K. cochlearis; Asa, A. saltans; Ghy, G. hyptopus; Sob, S. oblonga; Cco, C. cornuta; Dge, D. gessneri; Bde, B. deitersi; Bha, B. hagmani; Nhe, N. henseni; Tde, T. decipiens; Tmi, T. minutus).

D. gessneri on the rotifers and assigned this result to the fact that this species presented a high filtering efficiency.

\section{CONCLUSIONS}

In hydrodynamically homogeneous environments, such as the limnetic region of the lateral arm of the reservoir, the zooplankton community does not present significant differences in the abundance and species dominance over the area. However, considering the time scale, these attributes were significantly distinct over the sampling days.

Furthermore, not only does the availability of algae resource influence the abundance of the major zooplankton populations but a set of factors, including abiotic variables and biotic relationships (coexistence and competition), does as well. These results are consistent with the 'multiple forces' hypothesis and not in accordance to the study hypothesis.

Acknowledgements. The authors thank to Nupélia/UEM for the logistic support, CNPq-Pronex for financial support, CAPES for the doctoral scholarship to the first author and $\mathrm{CNPq}$ for the postdoctoral and Research Productivity scholarships. We also thank Ciro Y. Joko, Mariza Y. Nagae and Flávia S. Lima for help in the species identification and Dr. Luiz Felipe M. Velho for his valuable suggestions.

\section{REFERENCES}

Aoyagui, A. S. M.; Bonecker, C. C.; Lansac-Tôha, F. A. \& Velho, L. F. M. 2003. Estrutura e dinâmica dos rotíferos no reservatório de Corumbá, Estado de Goiás, Brasil. Acta Scientiarum, Biological Sciences 25(1):31-39.

Arcifa, M. S.; Gomes, E. T. \& Meschiatti, A. J. 1992. Composition and fluctuations of the zooplankton of a tropical Brazilian reservoir. Archiv für Hydrobiologie 123:479-495.

Bonecker, C. C. \& Lansac-TôHa, F. A. 1996. Community structure of rotifers in two environments of the high river Paraná floodplain (MS), Brazil. Hydrobiologia 325:137-150.

Bonecker, C. C.; Lansac-Tôha, F. A.; Bini, L. M. \& Velho, L. F. M. 2002. Daily fluctuation in rotifer population abundance in two environments of the upper Paraná River floodplain, Brazil. Amazoniana XVII:139-151.

Borges, P. A. F.; Train, S. \& Rodrigues, L. C. 2008. Estrutura do fitoplâncton, em curto período de tempo, em um braço do reservatório de Rosana (ribeirão do Corvo, Paraná, Brasil). Acta Scientiarum, Biological Sciences 30(1):57-65.

Bottrell, H. H.; Duncan, A.; Gliwicz, Z. M.; Gryiek, E.; Herzig, A.; Hillbricht-Ilkowska, A.; Kurasawa, H.; Larsson, P. \& WeglensKa, T. 1976. A review of some problems in zooplankton production studies. Norwergian Journal of Zoology 24:419-456.

CESP. 1998. Conservação e manejo nos reservatórios: limnologia, ictiologia e pesca. São Paulo, Série divulgação e informação 220. $166 \mathrm{p}$.

DEMот, W. R. 1989. The role of competition in zooplankton succession. In: Sommer, U. ed. Plankton Ecology. Berlin, Springer-Verlag. p.195-252.

DeMott, W. R. \& Kerfoot, W. C. 1982. Competition among cladocerans: nature of the interaction between Bosmina and Daphnia. Ecology 63:1949-1966.

Dodson, S. I. 1974. Zooplankton competition and predation. An experimental test of the size-efficiency hypothesis. Ecology 55:605613.

FonseCA, C. P. 1997. Plankton community dynamics over short periods at Jacaré-Pepira Reservoir, State of São Paulo, Brazil. Verhandlungen der Internationalen Vereinigung für Theoretische und Angewandte Limnologie 26:475-477.

Gilbert, J. J. 1988. Suppression of rotifer populations by Daphnia: a review of the evidence, the mechanisms and the effects on zooplankton community structure. Limnology and Oceanography 33:1286-1303.

Green, J. 1993. Diversity and dominance in planktonic rotifers. Hydrobiologia 255/256:345-352.

Hernández-Trujillo, S.; Gabriela Esqueda-Escárcega, G.; Hernández-Alfonso, J. R. \& Pacheco-ChÁvez, R. 2010. Variación diaria de la abundancia del zooplancton en Bahía Magdalena, B.C.S. México. Revista Mexicana de Biodiversidad 81:913-920.

Hoffmann, W. 1977. The influence of abiotic environmental factors on population dynamics in planktonic rotifers. Archiv für Hydrobiologie-Beiheft Ergebnisse der Limnologie 8:77-83.

Hutchinson, G. E. 1961. The Paradox of the Plankton. The American Naturalist 95(882):137-145.

JoHANSSON, S. 1983. Annual dynamics and production of rotifers in an eutrophication gradient in the Baltic Sea. Hydrobiologia 104:335340.

Kindt, R. \& Coe, R. 2005. Tree diversity analysis: A manual and software for common statistical methods for ecological and biodiversity studies. Nairobi, World Agroforestry Centre (ICRAF). 197p.

LAMPERT, W. \& SOMMER, U. 1997. Limnoecology: The ecology of lakes and streams. New York, Oxford University Press. 382p.

LANSAC-TÔHA, F. A.; Bonecker, C. C. \& Velho, L. F. M. 2005. Estrutura da comunidade zooplanctônica em reservatórios. In: RodRIGUES, L.; 
Thomaz, S. M.; Agostinho, A. A. \& Gomes, L. C. eds. Biocenoses em reservatórios: Padrões espaciais e temporais. São Carlos, RiMa. p.116-127.

Legendre, P. \& Gallagher, E. D. 2001. Ecologically meaningful transformations for ordination of species data. Oecologia 129:271280.

Legendre, P. \& Legendre, L. 1998. Numerical ecology. Amsterdam, Elsevier. 853p.

LEHMAN, J. T. 1988. Ecological principles affecting community structure and secondary production by zooplankton in marine and freshwater environments. Limnology and Oceanography 33:931-945.

Lienesch, P. W. \& Matthews, W. J. 2000. Daily fish and zooplankton abundances in the littoral zone of Lake Texoma, Oklahoma-Texas, in relation to abiotic variables. Environmental Biology of Fishes 59:271-283.

Lopes, R. M.; Lansac-Tôha, F. A.; Vale, R. \& Serafim JR., M. 1997. Comunidade zooplanctônica do reservatório de Segredo. In: Agostinho, A. A. \& Gomes, L. C. eds. Reservatório de Segredo: Bases ecológicas para o manejo. Maringá, EDUEM. p.39-60.

Mackereth, F. J. H.; Heron, J. \& Talling, J. F. 1978. Water analysis: some revised methods for limnologists. England, Freshwater Biological Association. 120p.

Marazzo, A. \& Valentin, J. L. 2000. Daily variation of marine cladoceran densities in a tropical bay - Brazil. Hydrobiologia 428:205-208.

Marzolf, G. R. 1990. Reservoirs as environments for zooplankton. In: Thornton, K.; Kimmel, B. L. \& Payne, F. E. eds. Reservoir limnology: ecological perspectives. New York, Wiley Interscience Publication v. 7. p.195-208.

Matsumura-Tundisi, T.; Leitão, S. N.; Aguena, L. S. \& Miyahara, J. 1990. Eutrofização da represa de Barra Bonita: Estrutura e organização da comunidade de Rotifera. Brazilian Journal of Biology 50:923935.

Matsumura-Tundisi, T. \& Tundisi, J. G. 2005. Plankton richness in a eutrophic reservoir (Barra Bonita Reservoir, SP, Brazil). Hydrobiologia 542:367-378.

Melão, M. G. G. 1999. Desenvolvimento e aspectos reprodutivos dos cladóceros e copépodos de águas continentais brasileiras. In: POMPÊO, M. L. M. ed. Perspectivas na Limnologia do Brasil. São Luís, Gráfica e Editora União. 198p.

Melão, M. G. G. \& RochA, O. 2006. Life history, population dynamics, standing biomass and production of Bosminopsis deitersi (Cladocera) in a shallow tropical reservoir. Acta Limnologica Brasiliensia 18:433-450.

Modenutti, B.; Queimaliños, C.; Balseiro, E. \& Reissig, M. 2003. Impact of different zooplankton structures on the microbial food web of a South Andean oligotrophic lake. Acta Oecologica 24:289-298.
Nogueira, M. C. 2001. Zooplankton composition, dominance and abundance as indicators of environmental compartmentalization in Jurumirim Reservoir (Paranapanema River, São Paulo, Brazil). Hydrobiologia 455:1-8.

Oksanen, J.; Blanchet, F. G.; Kindt, R.; Legendre, P.; Minchin, P. R.; O’Hara, R. B.; Simpson, G. L.; Solymos, P.; Stevens, M. H. H. \& Wagner, H. 2011. Vegan: Community Ecology Package. R package version 2.0-2.

Pielou, E. C. 1966. The measurement of diversity in different types of biological collection. Journal of Theoretical Biology 13:131-144.

Pinel-Alloul, B. \& Pont, D. 1991. Spatial distribution patterns in freshwater macrozooplankton: variation with scale. Canadian Journal of Zoology 69:1557-1570.

Pinel-Alloul, B. 1995. Spatial heterogeneity as a multiscale characteristic of zooplankton community. Hydrobiologia 300/301:17-42.

Pinel-Alloul, B.; Niyonsenga, T. \& Legendre, P. 1995. Spatial and environmental components of freshwater zooplankton structure. Ecoscience 2:1-19.

Pourriot, R. 1977. Food and feeding habitats of Rotifera. Archiv für Hydrobiologie 8:243-260.

R Development Core Team. 2011. R: Language and environment for statistical computing. $\mathbf{R}$ foundation for Statistical Computing. Available at $<$ http://www.r-project.org $>$.

Ramírez-Garcia, P.; NAndini, S.; SArma, S. S. S.; Robles Valderrama, E.; Cuesta, L. \& Hurtado, M. D. 2002. Seasonal variations of zooplankton abundance in the freshwater reservoir Valle de Bravo (Mexico). Hydrobiologia 467:99-108.

SANDERCOCK, G. A. 1967. A study of selected mechanisms for the coexistence of Diaptomus spp. in Clarke Lake, Ontario. Limnology and Oceanography 12:97-112.

SARNELle, O. 1997. Daphnia effects on microzooplankton: comparisons of enclosure and whole-lake experiments. Ecology 78:913-928.

SENDACZ, S. 1984. A study of the zooplankton community of Billings reservoir, São Paulo. Hydrobiologia 113:121-127.

SLÁDEČEK, V. 1983. Rotifers as indicators of water quality. Hydrobiologia 100:169-171.

Ter Braak, C. J. F. \& Prentice, I. C. 1988. The theory of gradient analysis. Advances in Ecological Research 18:271-317.

Villalobos, M. J. \& GonzÁlez, E. J. 2006. Estudios sobre la biología y ecología de Ceriodaphnia cornuta Sars: Una revisión. Interciencia 21:409-419.

Wetzel, R. G. \& Likens, G. E. 2000. Limnological analysis. New York, Springer-Verlag.

Williamson, C. E. 1983. Invertebrate predation on planktonic rotifers. Hydrobiologia 104:385-396. 